\title{
Frontières
}

\section{Lacrimae de Suzelle Levasseur}

La force paradoxale des larmes

\section{Laurier Lacroix}

Volume 21, numéro 2, printemps 2009

Détresse psychique et antidépresseurs

URI : https://id.erudit.org/iderudit/039463ar

DOI : https://doi.org/10.7202/039463ar

Aller au sommaire du numéro

Éditeur(s)

Université du Québec à Montréal

ISSN

1180-3479 (imprimé)

1916-0976 (numérique)

Découvrir la revue

Citer ce document

Lacroix, L. (2009). Lacrimae de Suzelle Levasseur : la force paradoxale des

larmes. Frontières, 21(2), 80-80. https://doi.org/10.7202/039463ar

Ce document est protégé par la loi sur le droit d'auteur. L'utilisation des services d'Érudit (y compris la reproduction) est assujettie à sa politique d'utilisation que vous pouvez consulter en ligne.

https://apropos.erudit.org/fr/usagers/politique-dutilisation/
Cet article est diffusé et préservé par Érudit.

Érudit est un consortium interuniversitaire sans but lucratif composé de l'Université de Montréal, l'Université Laval et l'Université du Québec à Montréal. Il a pour mission la promotion et la valorisation de la recherche. https://www.erudit.org/fr/ 


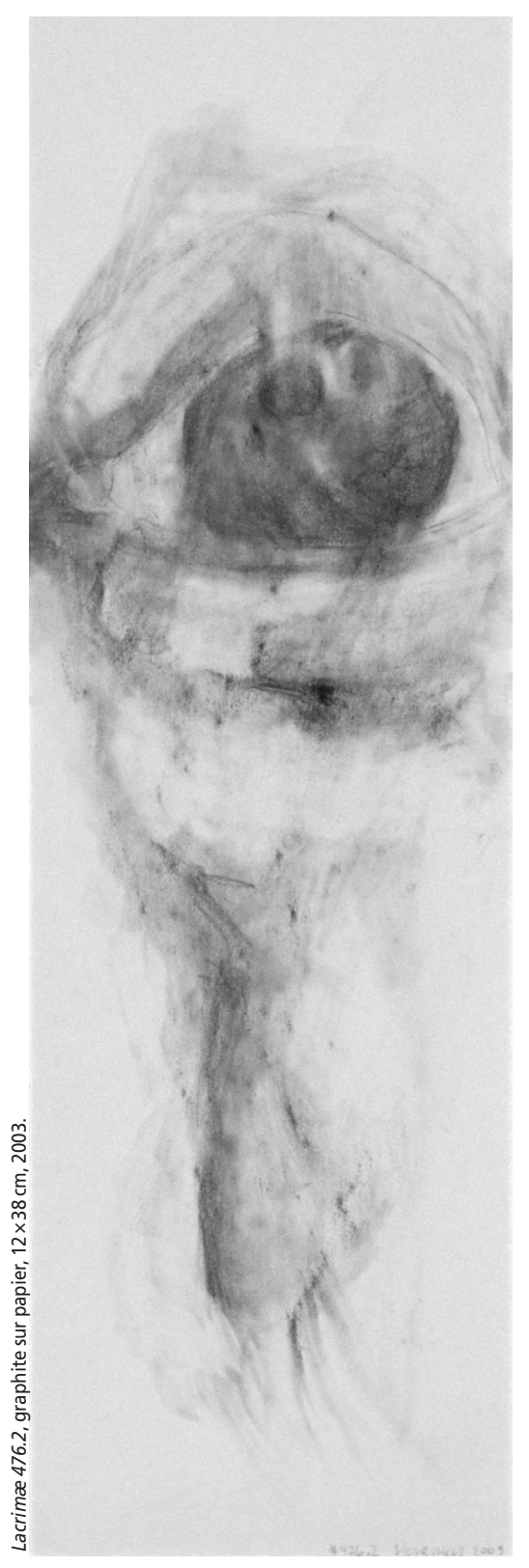

\section{LACRIMAE de Suzelle Levasseur \\ LA FORCE PARADOXALE DES LARMES}

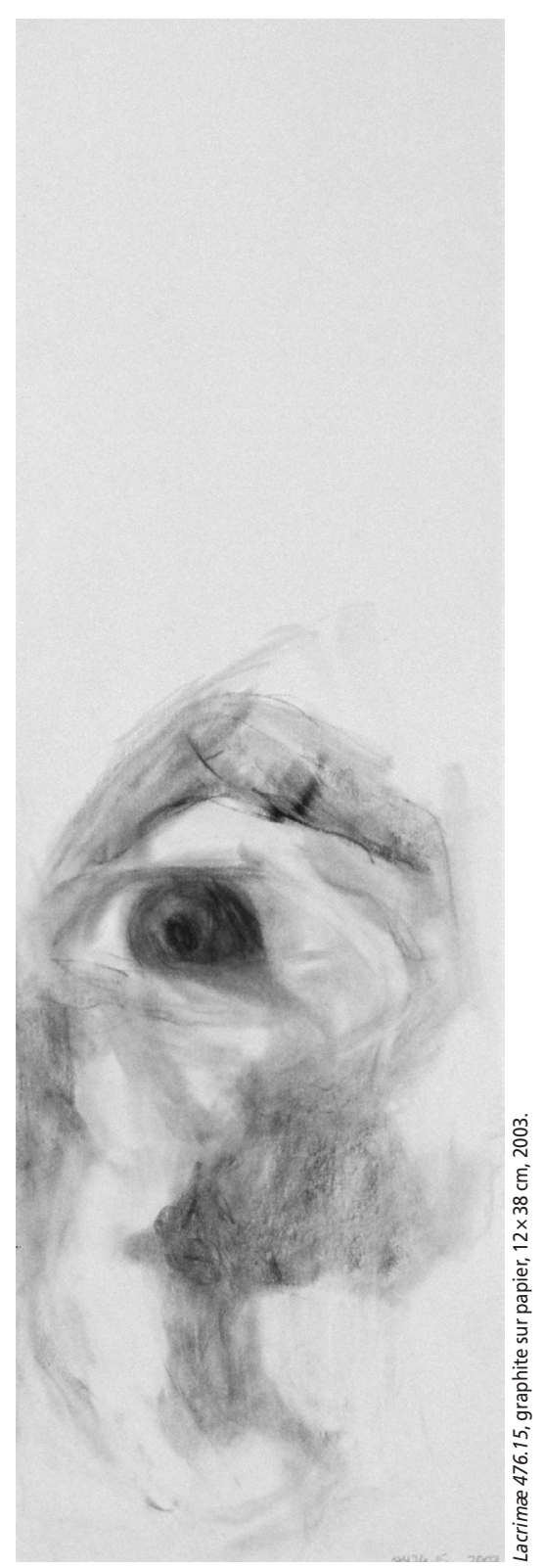

